\title{
EDITORIAL
}

\section{The International Academy of Sex Research: 40 Years On}

\author{
Kenneth J. Zucker
}

Published online: 3 December 2013

(C) Springer Science+Business Media New York 2013

On April 30, 1975, Saigon, the capital of South Vietnam (now Ho Chi Minh city), was liberated by the People's Army of Vietnam and the National Liberation Front. That was the end of the Vietnam war. Four-plus months later, on September 12-13, Richard Green, the founding President of the International Academy of Sex Research (IASR), convened its first annual meeting in Stony Brook, New York (see Green, 1985; Zucker, 2002). On the evening of September 11, there was an informal get-together in the local Holiday Inn bar in Stony Brook. No historical documents are available to verify if the end of the Vietnam war was toasted. The 1975 program listed 25 presenters: five of them (John Bancroft, David Barlow, James Geer, Richard Green, and Heino Meyer-Bahlburg) are current members of the IASR. Table 1 shows where we have been since 1975 .

In 2014, the IASR will holds its 40th annual meeting and thus will celebrate its "ruby" anniversary in Dubrovnik, Croatia, June 25-28, hosted by Alexsandar Štulhofer. I hope to see many of you there. Dress ruby at the banquet. Perhaps we will be able to toast the end of a contemporary war or civil conflict with a drink and twerk or two.
Table 1 From Stony Brook to Dubrovnik: The International Academy of Sex Research 40 years on

\begin{tabular}{|c|c|}
\hline Year & Meeting Site \\
\hline 1975 & Stony Brook, New York \\
\hline 1976 & Hamburg, West Germany \\
\hline 1977 & Bloomington, Indiana \\
\hline 1978 & Toronto, Ontario, Canada \\
\hline 1979 & Prague, Czechoslovakia \\
\hline 1980 & Tucson, Arizona \\
\hline 1981 & Haifa, Israel \\
\hline 1982 & Copenhagen, Denmark \\
\hline 1983 & Harriman, New York \\
\hline 1984 & Cambridge, England \\
\hline 1985 & Seattle, Washington \\
\hline 1986 & Amsterdam, The Netherlands \\
\hline 1987 & Tutzing, West Germany \\
\hline 1988 & Minneapolis, Minnesota \\
\hline 1989 & Princeton, New Jersey \\
\hline 1990 & Sigtuna, Sweden \\
\hline 1991 & Barrie, Ontario, Canada \\
\hline 1992 & Prague, Czech Republic \\
\hline 1993 & Pacific Grove, California \\
\hline 1994 & Edinburgh, Scotland \\
\hline 1995 & Provincetown, Massachusetts \\
\hline 1996 & Rotterdam, The Netherlands \\
\hline 1997 & Baton Rouge, Louisiana \\
\hline 1998 & Sirmione, Italy \\
\hline 1999 & Stony Brook, New York \\
\hline 2000 & Paris, France \\
\hline 2001 & Bromont, Quebec, Canada \\
\hline 2002 & Hamburg, Germany \\
\hline 2003 & Bloomington, Indiana \\
\hline 2004 & Helsinki, Finland \\
\hline
\end{tabular}

K. J. Zucker $(\bowtie)$

Gender Identity Service, Child, Youth, and Family Services,

Underserved Populations Program, Centre for Addiction and

Mental Health, 80 Workman Way, Toronto, ON M6J 1H4, Canada

e-mail: Ken.Zucker@camh.ca 
Table 1 continued

\begin{tabular}{ll}
\hline Year & Meeting Site \\
\hline 2005 & Ottawa, Ontario, Canada \\
2006 & Amsterdam, The Netherlands \\
2007 & Vancouver, British Columbia, Canada \\
2008 & Leuven, Belgium \\
2009 & San Juan, Puerto Rico \\
2010 & Prague, Czech Republic \\
2011 & Los Angeles, California \\
2012 & Estoril, Portugal \\
2013 & Chicago, Illinois \\
2014 & Dubrovnik, Croatia \\
\hline
\end{tabular}

\section{References}

Green, R. (1985). The International Academy of Sex Research: In the beginning. Archives of Sexual Behavior, 14, 293-302.

Zucker, K. J. (2002). On the history of the International Academy of Sex Research. Zeitschrift für Sexualforschung, 15, 142-146. 